\title{
Global concentrations of microplastics in soils - a review
}

\author{
Frederick Büks and Martin Kaupenjohann
}

\author{
Chair of Soil Science, Department of Ecology, Technische Universität Berlin, 10587 Berlin, Germany \\ Correspondence: Frederick Büks (frederick.bueks@ @u-berlin.de)
}

\author{
Received: 10 August 2020 - Discussion started: 1 September 2020 \\ Revised: 9 November 2020 - Accepted: 11 November 2020 - Published: 17 December 2020
}

\begin{abstract}
Worldwide, microplastics (MPs) have been commonly recognized as a threat to soil ecosystems. Terrestrial soils are widely contaminated by MPs due to the application of sewage sludge and wastewater, plastic mulching, littering, the input of tire wear from roads and atmospheric deposition. Within the last decade, an increasing number of individual studies focused on item counts and masses of MPs in different global soil environments.

We reviewed these studies to achieve a representative picture of common degrees of contamination. The majority of the prospected agricultural and horticultural sites were exposed to sewage sludge and mulching film application and showed concentrations of $<13000$ items kg$~^{-1}$ dry soil and $4.5 \mathrm{mg} \mathrm{kg}^{-1}$ dry soil. Microplastic concentrations in soils in the vicinity of municipal areas were thereby 10 times larger compared to rural sites. The measurement of masses was generally underrepresented compared to item numbers, and mass data were often generated from microscopic analyses by using shape-to-mass models instead of direct measurements. Extreme values, such as on industrial sites, exceed the common concentrations by 2 to 4 orders of magnitude, which might be attributed not only to the land use but also to the applied methods of measurement. Campaigns that focus on other entry pathways like composts, road dust runoff and littering or land uses like grassland, forest, fallow and wilderness as well as industrial sites and landfills were underrepresented or nonexistent. Background loads, such as atmospheric deposition, were often not excluded from the measurements and, thus, the studies might overestimate the contribution of the analyzed entry pathway to the total load. Other studies focused on light density MP, e.g., from mulching films, and therefore underestimated the amount of soil MP.

Despite these limitations, the data give an impression of the spectrum of global MP concentrations and are a good basis for experiments examining the effects of MPs on exposed soils. Based on the collected data, we identified problems of past studies and recommend that future experimentation take into account standardized methods of extraction and quantification, a proper characterization of the sampling sites and their history as well as the exploration of as yet underrepresented entry pathways and land uses.
\end{abstract}

\section{Introduction}

The impact of microplastics (MPs) on global ecosystems is widely accepted and discussed in many comprehensive reviews (e.g., Lambert et al., 2014; Bläsing and Amelung, 2018; Ng et al., 2018; Schell et al., 2020). The contamination of the environment with plastic waste started to raise our awareness of this extraordinary stable material step by step when seabirds were found, in the early 1960s, perished with their guts full of plastic debris (Thompson et al., 2009). Microplastic, then, started to be recognized in the marine envi- ronment during the 1970s, when, for example, Gregory et al. (1978) reported high counts of it on New Zealand beaches. Thus, the early research on MPs was mainly focused on marine and limnic environments, today resulting in a multitude of studies and early comprehensive data on marine or inland waters compared to studies on terrestrial environments. At first, soils were ignored.

Plastic most probably accessed the manifold soil environments when petroleum-based consumer products like fashion made of synthetic fibers entered markets in the second half of the 20th century (Geyer et al., 2017). Today, the in- 


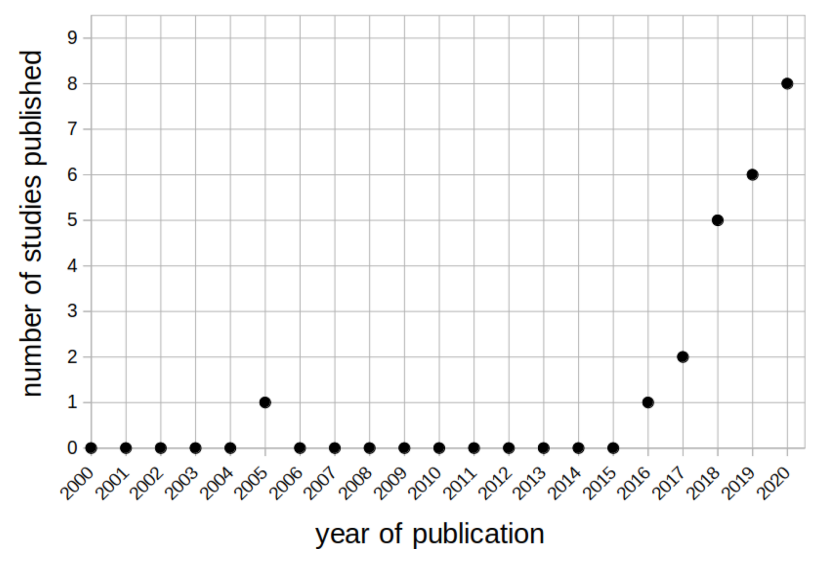

Figure 1. Number of studies on microplastic concentrations in terrestrial soils published since the year 2000 .

put pathways of MPs to agriculture, horticulture, orchards, grassland and forest soils comprise the application of sewage sludge (and also most probably digestates and composts of it), waste waters, composted and fermented organic waste products, the weathering and - in extreme cases - plowing of mulching foils as well as irrigation with water from contaminated lakes or rivers (Steinmetz et al., 2016; Bläsing and Amelung, 2018; Weithmann et al., 2018). Also the littering, decay and comminution of plastic wastes (Huerta Lwanga et al., 2017), the dispersion from inappropriately managed landfills by leaching (Praagh et al., 2018; He et al., 2019) and the eolian transport of small-sized MPs cause the input to different soil ecosystems even in remote areas (Rezaei et al., 2019). Littoral areas, such as floodplains, river banks, tidal flats and beaches, additionally receive regular inputs of MPs by diffuse sources through the aquatic environment (Barnes et al., 2009). Evidence suggests that regular application of MPs leads to significant accumulation in soils (Corradini et al., 2019; van den Berg et al., 2020).

Dumped into the soil, MPs are supposed to influence physical properties, such as the water-holding capacity (WHC), processes like soil aggregation, the performance and composition of the soil microbial community, the soil fauna and the flora (de Souza Machado et al., 2018; Lehmann et al., 2019; Rillig et al., 2019; Büks et al., 2020a; Fei et al., 2020). Although the number of studies on MPs in soil environments has been rising in the last decade (Fig. 1), there is still little knowledge of the concentrations of MPs and the relation to adverse effects.

The broad collection of data on the range of MP concentration, type, shape and size in global soils is fundamental for the appropriate design of studies on physiochemical and biological effects of soil MPs. Within the European Union, there is, to date, no legislation on monitoring soil MPs, which could provide these data. Ongoing research projects, which focus on impact assessments, struggle with the lack of knowledge of concentrations and properties of environmental MPs when experimental setups are applied.

To overcome this lack of information, soil MP concentrations were recently predicted by input models. Nizzetto et al. (2016) estimated that, due to the application of sewage sludge, the load of MPs to European agricultural sites is $5.8 \mathrm{~kg} \mathrm{ha}^{-1} \mathrm{a}^{-1}\left(1.6 \mathrm{mg} \mathrm{kg}^{-1} \mathrm{a}^{-1}\right)$. Similar calculations, based on the production of sewage sludge in Germany or the threshold for the application of sewage sludge, deviate from this value only by 1 order of magnitude (Büks et al., 2020b).

The aim of this review is to collect data about common soil MP concentrations, sizes, shapes and types under the influence of different anthropogenic parameters, discuss the robustness of these data and give recommendations for future experiments. We focus on terrestrial soils and exclude subhydric and semi-subhydric sites such as river and lake shores, beaches, tidal flats, mangroves and lagoons. Studies on such systems that appeared some years earlier than investigations on terrestrial sites are more numerous, in parts very comprehensive, and provide, together with manifold local studies, a more equally distributed global data then ever collected for soil MPs (e.g., Lots et al., 2017; Eo et al., 2018; Karthik et al., 2018; Scheurer and Bigalke, 2018; Yu et al. 2018).

\section{Method}

Our search was conducted by using the Web of Science Core Collection database and covering 23 studies with $n=223$ sampling sites published until August 2020 (Fig. 2). The search pattern contained the word "microplastic", linked in all possible combinations, with each one of eight land use types (the general terms of soil, agriculture, horticulture, orchard, grassland, fallow, forest and landfill) and one of nine origins of MPs (sewage sludge, waste water, plastic mulching, compost, digestates, road and tire wear, littering, flooding/ponding and eolian transport). The studies were searched for data on location, soil type, land use, origin of MPs, vicinity (municipal, rural or industrial), sampling depth, method of MP extraction and measurement, type, size and shape of MPs as well as MP concentrations based on mass $\left(\mathrm{mg} \mathrm{kg}^{-1}\right)$, items (items kg${ }^{-1}$ ) and particle surface $\left(\mathrm{mm}^{2} \mathrm{~kg}^{-1}\right)$. All data refer to dry soil.

Wherever possible, our approach uses one concentration value per each separated sampling site. Sites were considered as separated if they represented spatially separated landscapes, were differently managed or had clearly different soil properties. Some studies published multiple data sets on single sampling sites. In order to avoid statistical overvaluation of these sites, the data were pooled. Other studies, however, pooled values from different localities to achieve more compact data. To compensate for the loss in information, these data were regrouped based on the values provided in the published paper, the Supplement or by use of raw data given by the authors. Data was also pooled if it was not clear whether 


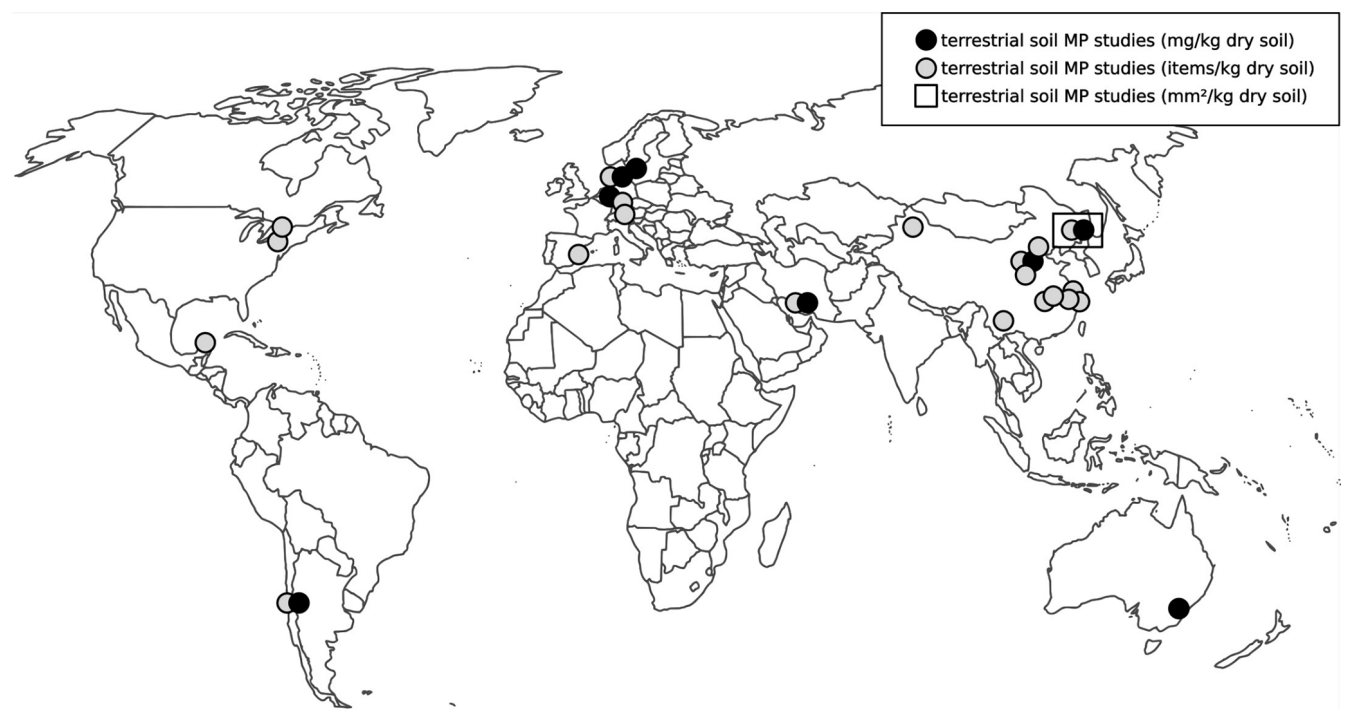

Figure 2. Global distribution of studies on soil microplastic concentrations (status - August 2020).

it came from the same site. Data taken from different layers of the topsoil (e.g., $0-10$ and $10-20 \mathrm{~cm}$ ) were averaged to gain weighted mean concentrations. In some cases, values could only be roughly extracted from figures but with sufficient accuracy for the purpose of this work. If no raw data were provided by the authors and no structural adaptation of data was possible at all, the number of pooled sites was noted and the average value was considered as one site. Detailed information can be found in the Supplement.

Whenever median, minimum (min) and maximum (max) values were available, these data were favored over mean values \pm standard deviation (SD). Stocks (per hectare) were converted to concentrations based on $1.2 \mathrm{~g} \mathrm{~cm}^{-3}$ soil bulk density, regardless of the soil type. For the presentation of concentration ranges depending on the origin of MP, land use and vicinity, these data were grouped, and the average values (medians and mean values) and extrema (min and max values, mean values $\pm \mathrm{SD}$ ) were plotted together with their collective median and interquartile range $(25 \%$ and $75 \%$ quantiles). As these metrics are partly derived from pooled values, the calculated quantiles do not exactly represent the real quantiles. This is the reason why a strong statistical analysis was not applied in this work.

\section{Synopsis of regional microplastic concentrations}

The 23 studies of this review were found to be very unevenly distributed around the globe. In China, the only country in eastern Asia that performed MP measurements, 11 regional studies with 155 sites were carried out, mainly in the east coast and the central region. On the European continent, six studies with 34 sites took place in Austria, Germany, Scandinavia and Spain, whereas no research was found for sites in other European countries, including Russia. North Amer- ica has two studies with eight sites, restricted to the northern regions. Only one study was carried out in Australia (one site), the Middle East (10), South America (five) and Central America (10), while Africa and the Indian subcontinent - certainly affected by the contamination of terrestrial soils with MPs as well - have not yet conducted investigations.

\subsection{East Asia}

In China, investigations were carried out in part with an extensive number of sampling sites per study (Table 1). Most of the studies are structured very similarly, using mechanical agitation within a salt solution for the detachment and density separation of MP. In two cases, there was a foregoing, and in six cases, additional oxidation of soil organic matter with $\mathrm{H}_{2} \mathrm{O}_{2}$ or other oxidants was applied, followed by light microscopy (LM) and Fourier transform infrared (FTIR) spectroscopy for particle counting and identification of MPs (Liu et al., 2018; Zhang and Liu, 2018; Zhang et al., 2018, 2020; Han et al., 2019; Lv et al., 2019; Zhou et al., 2019, 2020; Chen et al., 2020; Ding et al., 2020; Huang et al., 2020). The 11 studies showed a median MP particle number of 1076 items $\mathrm{kg}^{-1}$, with a $25 \%$ quantile of 78 items kg-1, a $75 \%$ quantile of 2500 items kg-1 and a maximum of 690000 items $\mathrm{kg}^{-1}$.

Three of these studies focused on the mixed origins of soil MPs and found average concentrations of 2625 items kg $\mathrm{kg}^{-1}$ $\left(n=38 ; 25 \%-1875\right.$ items kg ${ }^{-1} ; 75 \%-14198$ items kg $\left.{ }^{-1}\right)$, while no mass data were recorded (Zhang and Liu, 2018; Zhou et al., 2019; Ding et al., 2020). Agricultural land that received sewage sludge application and plastic mulching was examined by Ding et al. (2020) in the vicinity of nine cities across the Shaanxi province. The authors applied density fractionation (DF) with a cut-off of 
Table 1. Studies on microplastic concentrations with characterization of sites, applied methods and extracted microplastic samples. The abbreviations used in this table are as follows: hort - horticulture; agr - agriculture; gra - grassland; orch - orchard; for - forest; fal fallow; sew - sewage sludge application; pm - plastic mulching; pg - plastic greenhouses; lit - littering; ww - waste water; $\mathrm{S}$ - stirring; U - ultrasonication; AM - air mixing; DF - density fractionation; SDS - sodium dodecyl sulfate; LM - light microscopy; FTIR - Fourier transform infrared spectroscopy; Pyr-GC-MS - pyrolysis-gas chromatography-mass spectrometry; Raman - Raman spectroscopy; fib fibers; mb - microbeads; frag - fragments; pel - pellets; $\mathrm{G}$ - Gleysol; N - Nitisol; dw - dry weight. Information indicated in bold means that the specific type of microplastic was found. NA denotes that information was not available. Detailed data are listed in the Supplement.

\begin{tabular}{|c|c|c|c|c|c|c|c|c|c|c|c|c|c|}
\hline Region & Sites & $\begin{array}{c}\text { Land } \\
\text { use }\end{array}$ & $\begin{array}{c}\text { Entry } \\
\text { pathway }\end{array}$ & Vicinity & $\begin{array}{l}\text { Sampling depth } \\
(\mathrm{cm})\end{array}$ & Method of extraction & $\begin{array}{c}\text { Method of } \\
\text { quantification/ } \\
\text { qualification }\end{array}$ & $\begin{array}{l}\text { Measured plastic } \\
\text { type (bold=found) }\end{array}$ & $\begin{array}{c}\mathrm{mg} \mathrm{kg}^{\mathbf{1}} \mathbf{d w} \\
\mathrm{mv} \pm \mathrm{sd} \\
\operatorname{median~(min-max)~}\end{array}$ & $\begin{array}{l}\text { Items } \mathbf{k g}^{-1} \mathbf{d} \mathbf{d w} \mathbf{m v} \pm \mathrm{sd} \\
\text { median }(\min -\max )\end{array}$ & Size span $(\mu \mathrm{m})$ & Shape & Reference \\
\hline Wǔhàn, 武汉市 (China) & $\begin{array}{c}8 \\
12 \\
\end{array}$ & $\begin{array}{l}\text { hort } \\
\text { hort }\end{array}$ & $\begin{array}{l}\mathrm{NA} \\
\text { road }\end{array}$ & Municipal & NA & S-DF $\left(\mathrm{ZnCl}_{2} 1.5 \mathrm{~g} \mathrm{~cm}^{-3}\right)$ & LM, Raman & $\begin{array}{c}\mathrm{PA}, \mathrm{PP}>\mathrm{PS}, \mathrm{PVC}> \\
\mathrm{PE}\end{array}$ & NA & $\begin{array}{c}1083(600-3167) \\
1142(300-12500)\end{array}$ & $\begin{array}{l}20-5000 \\
70 \%<200\end{array}$ & fib,mb>frag & Chen et al. (2020) \\
\hline $\begin{array}{l}\text { Región Metropolitana } \\
\text { de Santiago } \\
\text { (Chile) }\end{array}$ & $\begin{array}{l}1 \\
1 \\
1 \\
1 \\
1 \\
\end{array}$ & $\begin{array}{l}\text { agr } \\
\text { agr } \\
\text { agr } \\
\text { agr } \\
\text { agr }\end{array}$ & $\begin{array}{l}\text { Sew }(1 x) \\
\text { Sew }(2 x) \\
\text { Sew (3x) } \\
\text { Sew (4x) } \\
\text { Sew (5x) } \\
\end{array}$ & Municipal & $0-25$ & $\begin{array}{l}\text { S-DF (water, NaCl } 1.2 \mathrm{~g} \\
\left.\mathrm{~cm}^{-3}, \mathrm{ZnCl}_{2} 1.55 \mathrm{~g} \mathrm{~cm}^{-3}\right)\end{array}$ & $\begin{array}{l}L M, \\
\text { shape to mass }\end{array}$ & NA & $\begin{array}{l}1.4(0.7-2.2) \\
2.0(1.8-3.2) \\
2.2(0.6-4.6) \\
2.9(1.8-12.9) \\
4.4(1.8-10.3) \\
\end{array}$ & $\begin{array}{c}1200(0-2200) \\
1800(1200-3200) \\
1200(200-4400) \\
2200(800-12400) \\
3600(1000-10200)\end{array}$ & $\begin{array}{l}<5000 \\
\text { Mainly }<1000 \times 50\end{array}$ & fib >>others & Corradini et al. (2019) \\
\hline $\begin{array}{l}\text { Southeast Ontario } \\
\text { (Canada) }\end{array}$ & $\begin{array}{l}1 \\
2 \\
1\end{array}$ & $\begin{array}{l}\text { agr } \\
\text { agr } \\
\text { agr }\end{array}$ & $\begin{array}{l}\text { No sew } \\
\text { Sew (1x) } \\
\text { Sew (2x) }\end{array}$ & Rural & $0-5,5-10,10-15$ & Fenton's reagent, DF & LM, FTIR & $\begin{array}{l}\text { PS, PE, PP, PU, } \\
\text { polyester, others }\end{array}$ & NA & $\begin{array}{c}4 \pm N A \\
103 \pm 52 \\
541 \pm 305\end{array}$ & NA & fib>rrag & Crossman et al. (2020) \\
\hline Köln (Germany) & 1 & NA & Road & Municipal & NA & PFE & Pyr-GC-MS & $\mathrm{PE}>\mathrm{PP}, \mathrm{PS}$ & $915 \pm 63$ & NA & NA & NA & Dierkes et al. (2019) \\
\hline $\begin{array}{l}\text { Shanxi Province, 陕西省 } \\
\text { (Chinn) }\end{array}$ & 9 & agr & pm, sew & Municipal & NA & $\begin{array}{l}\text { S-DF }\left(\mathrm{NaCl} 1.2 \mathrm{~g} \mathrm{~cm}^{-3}\right. \\
\left.\mathrm{CaCl}_{2} 1.5 \mathrm{~g} \mathrm{~cm}^{3}\right), \mathrm{H}_{2} \mathrm{O}_{2}\end{array}$ & LM, FTIR & $\begin{array}{l}\text { PE, PET, PP, PS, } \\
\text { PVC }\end{array}$ & NA & $2131 \pm 371$ & $\begin{array}{c}<5000 \\
\text { Mainly }<500\end{array}$ & fib>frag>other & Ding et al. (2020) \\
\hline $\begin{array}{c}\text { Sydney } \\
\text { (Australia) }\end{array}$ & 1 & NA & NA & Industrial & NA & PFE & $\begin{array}{l}\text { Gravimetric, } \\
\text { FTIR }\end{array}$ & $\begin{array}{c}\text { PE, PS, PVC, PP, } \\
\text { PET }\end{array}$ & $2400(300-67500)$ & NA & $<1000$ & NA & Fuller and Gautam (2016) \\
\hline $\begin{array}{c}\begin{array}{c}\text { Tiänjīin, 天津市 } \\
\text { (China) }\end{array} \\
\end{array}$ & 1 & NA & NA & Municipal & NA & $\begin{array}{c}\text { AM-DF }(\mathrm{NaCl}+\mathrm{Nal} \\
\left.1.5 \mathrm{~g} \mathrm{~cm}^{-3}\right), \mathrm{H}_{2} \mathrm{O}_{2}\end{array}$ & LM, FTIR & PP & NA & 95 & $<3200$ & frag & Han et al. (2019) \\
\hline $\begin{array}{l}\text { Shinhézí, 石河子市 } \\
\text { (China) }\end{array}$ & $\begin{array}{l}1 \\
1 \\
1\end{array}$ & $\begin{array}{l}\text { agr } \\
\text { agr } \\
\text { agr }\end{array}$ & $\begin{array}{l}\mathrm{pm}(5 \mathrm{yr}) \\
\mathrm{pm}(15 \mathrm{yr}) \\
\mathrm{pm}(24 \mathrm{yr})\end{array}$ & Municipal & $0-40$ & $\begin{array}{c}\mathrm{S}-\mathrm{DF}\left(\mathrm{Nal} 1.85 \mathrm{~g} \mathrm{~cm}^{-3}\right), \\
\mathrm{H}_{2} \mathrm{O}_{2}\end{array}$ & LM, FTIR & $\mathrm{PE}$ & NA & $\begin{array}{c}80 \pm 49 \\
308 \pm 138 \\
1076 \pm 347 \\
\end{array}$ & $<5000$ & frag & Huang et al. (2020) \\
\hline $\begin{array}{l}\text { Yucatan Peninsula } \\
\text { (Mexico) }\end{array}$ & 10 & hort & lit & Rural & $0-10,10-20$ & U-DF (water) & LM & NA & NA & $870 \pm 1900$ & $\begin{array}{l}<2000 \\
95 \%<50 \\
\end{array}$ & NA & $\begin{array}{l}\text { Huerta Lwanga et al. } \\
\text { (2017) }\end{array}$ \\
\hline $\begin{array}{l}\text { Shànghăi, 上海市 } \\
\text { (China) }\end{array}$ & 20 & hort & $\mathrm{pg}, \mathrm{pm}$ & Municipal & $0-3,3-6$ & 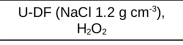 & LM, FTIR & $\mathrm{PP}, \mathrm{PE}>$ polyester & NA & $70 \pm 13$ & $\begin{array}{c}20-10000 \\
54 \%<1000\end{array}$ & $\begin{array}{l}\text { fibsfrag> } \\
\text { films>pel }\end{array}$ & Liu et al. (2018) \\
\hline $\begin{array}{l}\text { Malmö } \\
\text { (Sweden) }\end{array}$ & $\begin{array}{l}1 \\
1 \\
1\end{array}$ & $\begin{array}{l}\text { agr } \\
\text { agr } \\
\text { agr }\end{array}$ & $\begin{array}{c}\text { No sew } \\
\text { Sew } \\
(1 \text { tha-1 } \\
\left.\text { Sew } a^{-1}\right) \\
\left(3 \text { tha } a^{-1} \mathrm{a}^{-1}\right) \\
\end{array}$ & Municipal & $0-20$ & $\begin{array}{c}\mathrm{H}_{2} \mathrm{O}_{2}+\text { enzymes, DF }\left(\mathrm{ZnCl}_{2}\right. \\
\left.1.7 \mathrm{~g} \mathrm{~cm}^{-3}\right)\end{array}$ & $\begin{array}{l}\text { LM, FTIR, } \\
\text { shape to mass }\end{array}$ & Diverse & $\begin{array}{l}0.3 \\
0.3 \\
3.4\end{array}$ & NA & $10-5000$ & NA & Ljung et al. (2018) \\
\hline $\begin{array}{l}\text { Shànghăi, 上海市 } \\
\text { (China) }\end{array}$ & $\begin{array}{l}3 \\
3\end{array}$ & $\begin{array}{l}\text { rice } \\
\text { rice- } \\
\text { fish }\end{array}$ & Ponding & Municipal & $0-10$ & $\begin{array}{c}\text { S-DF }\left(\mathrm{NaCl} 1.24 \mathrm{~g} \mathrm{~cm}^{3}\right) \\
\mathrm{H}_{2} \mathrm{O}_{2}\end{array}$ & LM, FTIR & NA & NA & $\begin{array}{c}12 \pm 4 \\
4 \pm 2\end{array}$ & $>20$ & fib, frag & Lvet al. (2019) \\
\hline $\begin{array}{l}\text { Austria/Southern } \\
\text { Germany }\end{array}$ & 11 & NA & NA & Municipal & NA & $\begin{array}{c}\mathrm{H}_{2} \mathrm{O}_{2}, \mathrm{U}-\mathrm{DF} \\
\left(\mathrm{ZnCl}_{2} 1.45 \mathrm{~g} \mathrm{~cm}^{-3}\right)\end{array}$ & LM & NA & NA & $11 \times 10^{6}\left(2 \times 10^{6}-26 \times 10^{6}\right)$ & 5-1000 & NA & Meixner et al. (2020) \\
\hline $\begin{array}{c}\text { Mittelfranken } \\
\text { (Germany) }\end{array}$ & 1 & agr & None & Rural & $0-5$ & $\mathrm{H}_{2} \mathrm{O}_{2,}$ sieving & LM, FTIR & $P E, P P, P S$ & NA & $0.3(0.0-1.3)$ & $1000-5000$ & $\begin{array}{l}\text { films sfrag> } \\
\text { others }\end{array}$ & Piehl et al. (2018) \\
\hline $\begin{array}{l}\text { Fars province, فارس } \\
\text { (Iran) }\end{array}$ & $\begin{array}{l}5 \\
5 \\
\end{array}$ & $\begin{array}{l}\text { agr } \\
\text { gra }\end{array}$ & $\begin{array}{l}\mathrm{pm} \\
\mathrm{NA}\end{array}$ & Rural & $0-10$ & S+U-DF (water) & $\begin{array}{l}\text { LM, } \\
\text { shape to mass }\end{array}$ & NA & $\begin{array}{l}1.2 \pm 0.6 \\
0.2 \pm 0.1\end{array}$ & $\begin{array}{c}205 \pm 186 \\
38 \pm 17\end{array}$ & $\begin{array}{c}40-740 \\
\text { Mainly }<100\end{array}$ & NA & Rezaei et al. (2019) \\
\hline $\begin{array}{l}\text { València } \\
\text { (Spain) }\end{array}$ & $\begin{array}{l}1 \\
1 \\
1 \\
1 \\
1 \\
1 \\
1 \\
1 \\
1 \\
1 \\
1 \\
1 \\
1 \\
1 \\
1 \\
1 \\
\end{array}$ & $\begin{array}{l}\text { agr } \\
\text { agr } \\
\text { agr } \\
\text { agr } \\
\text { ggr } \\
\text { agr } \\
\text { agr } \\
\text { agr } \\
\text { agr } \\
\text { agr } \\
\text { agr } \\
\text { agr } \\
\text { agr } \\
\text { agr } \\
\text { orch } \\
\text { orch }\end{array}$ & $\begin{array}{l}\text { Sew }(1 x) \\
\text { Sew (3x) } \\
\text { Sew (3x) } \\
\text { Sew (3x) } \\
\text { Sew (4x) } \\
\text { Sew (4x) } \\
\text { Sew (5x) } \\
\text { Sew (5x) } \\
\text { Sew (6x) } \\
\text { Sew (8x) } \\
\text { Sew (8x) } \\
\text { No sew } \\
\text { No sew } \\
\text { No sew } \\
\text { No sew } \\
\text { No sew }\end{array}$ & $\begin{array}{c}\text { Rural } \\
\text { Rural } \\
\text { NA } \\
\text { Rural } \\
\text { Rural } \\
\text { NA } \\
\text { Rural } \\
\text { NA } \\
\text { Rural } \\
\text { Rural } \\
\text { NA } \\
\text { Municipal } \\
\text { NA } \\
\text { Rural } \\
\text { Rural } \\
\text { NA } \\
\end{array}$ & $0-10,10-30$ & $\begin{array}{l}\text { S-DF (water, } \\
\left.\text { Nal } 1.7 \mathrm{~g} \mathrm{~cm}^{-3}\right)\end{array}$ & LM, FTIR & NA & NA & $\begin{array}{c}1499(999-1998) \\
2664(999-3996) \\
1998(999-3663) \\
2830(1998-3330) \\
5328(1332-6327) \\
3330(1998-3996) \\
7659(7326-7992) \\
3330(1998-5328) \\
2997(2331-5994) \\
3996(1998-8648) \\
2831(1665-5994) \\
2498(333-4662) \\
999(333-2331) \\
500(0-1332) \\
999(0-1332) \\
2664(999-2664) \\
\end{array}$ & $>11$ & frag >>fib,films & van den Berg et al. (2020) \\
\hline Denmark & $\begin{array}{l}1 \\
1\end{array}$ & $\begin{array}{l}\text { agr } \\
\text { agr }\end{array}$ & $\begin{array}{l}\text { Sew } \\
\text { No sew }\end{array}$ & NA & $0-15$ & $\begin{array}{l}\text { SDS, S-DF (water, } \\
\left.\text { ZnCI } 1.7 \mathrm{~g} \mathrm{~cm}^{-3}\right)\end{array}$ & $\begin{array}{l}\text { LM, FTIR, } \\
\text { shape to mass }\end{array}$ & $\begin{array}{l}\mathrm{PP}>\mathrm{PE} \gg>\text { nylon } \\
\mathrm{PE} \gg>\text { nylon }>\mathrm{PP}\end{array}$ & $\begin{array}{l}5.8(0.0-16.5) \\
12.0(0.1-224)\end{array}$ & $\begin{array}{c}71000(0-165000) \\
145000(53000- \\
528000)\end{array}$ & $20-500$ & NA & $\begin{array}{l}\text { Vollertsen } \\
\text { and Hansen (2017) }\end{array}$ \\
\hline $\begin{array}{l}\text { Kūnmíng, 昆明市 } \\
\text { (China) }\end{array}$ & $\begin{array}{l}2(\mathrm{G}) \\
2(\mathrm{~N}) \\
1(\mathrm{G}) \\
\end{array}$ & $\begin{array}{l}\text { agr } \\
\text { agr } \\
\text { for }\end{array}$ & $\begin{array}{l}\text { pg, sew, ww } \\
\text { pg, sew, ww } \\
\text { NA }\end{array}$ & Municipal & $0-5,5-10$ & $\begin{array}{c}\mathrm{NaOH}+\mathrm{H}_{2} \mathrm{O}_{2}, \mathrm{U}-\mathrm{DF} \text { (water, } \\
\left.\mathrm{Nal} 1.8 \mathrm{~g} \mathrm{~cm}^{3}\right)\end{array}$ & LM & NA & NA & $\begin{array}{l}26070(13470-42960) \\
12050(7100-26630) \\
14440(8180-18100)\end{array}$ & $\begin{array}{l}50-10000, \\
95 \%<1000, \\
82 \%<250\end{array}$ & fib $>>0$ thers & Zhang and Liu (2018) \\
\hline $\begin{array}{l}\text { Loess Plateau, 黃土高原 } \\
\text { (China) }\end{array}$ & $\begin{array}{l}1 \\
1 \\
1\end{array}$ & $\begin{array}{l}\text { agr } \\
\text { orch } \\
\text { hort }\end{array}$ & $\begin{array}{l}\text { pm } \\
\text { NA } \\
\text { NA }\end{array}$ & Rural & $0-10,10-30$ & S+U-DF (water) & $\begin{array}{l}\text { LM, } \\
\text { shape to mass }\end{array}$ & LD-PE, PP & $\begin{array}{l}0.3 \pm 0.5 \\
0.5 \pm 0.7 \\
0.1 \pm 0.1\end{array}$ & $\begin{array}{l}80 \pm 136 \\
187 \pm 222 \\
87 \pm 213\end{array}$ & Mainly $>100$ & NA & Zhang et al. (2018) \\
\hline $\begin{array}{l}\text { Hāěrbīin, 哈尔溟市 } \\
\text { (China) }\end{array}$ & $\begin{array}{l}2 \\
2\end{array}$ & $\begin{array}{l}\text { agr } \\
\text { agr }\end{array}$ & $\begin{array}{l}\mathrm{pm} \\
\mathrm{pm}\end{array}$ & $\begin{array}{c}\text { Municipal } \\
\text { Rural }\end{array}$ & $0-20(0-30)$ & DF (water) & $\begin{array}{c}\text { LM, FTIR, } \\
\text { shape to mass }\end{array}$ & NA & $\begin{array}{l}0.1 \pm 0.6 \\
0.0 \pm 0.0\end{array}$ & $\begin{array}{c}163 \pm 250 \\
75 \pm 130\end{array}$ & $\begin{array}{c}50-5000 \\
\text { Mainly }>100\end{array}$ & NA & Zhang et al. (2020) \\
\hline $\begin{array}{l}\text { Wuhàn, 武汉市 } \\
\text { (China) }\end{array}$ & $\begin{array}{l}10 \\
7 \\
7\end{array}$ & $\begin{array}{l}\text { hort } \\
\text { for } \\
\text { fal }\end{array}$ & $\begin{array}{l}\mathrm{pm}, \text { sew, ww } \\
\mathrm{pm} \text {, sew, ww } \\
\mathrm{pm}, \text { sew, ww }\end{array}$ & $\begin{array}{c}\text { Mainly } \\
\text { industrial }\end{array}$ & at 5 & $\begin{array}{l}\mathrm{KOH}+\mathrm{NaClO}, \mathrm{S}+\mathrm{U}-\mathrm{DF} \\
\left(\mathrm{NaCl} 1.19 \mathrm{~g} \mathrm{~cm}^{-3}\right. \\
\left.\mathrm{ZnCl}_{2} 1.55 \mathrm{~g} \mathrm{~cm}^{-3}\right)\end{array}$ & LM, Raman & $\mathrm{PE}>\mathrm{PA}, \mathrm{PP}, \mathrm{PS}$ & NA & $\begin{array}{l}43000-620000 \\
96000-690000 \\
22000-200000\end{array}$ & $\begin{array}{l}10-5000 \\
82 \%<100\end{array}$ & frag >>others & Zhou et al. (2019) \\
\hline $\begin{array}{l}\text { Hangzhou Bay, 杭州湾 } \\
\text { (China) }\end{array}$ & 60 & agr & $\mathrm{pm}$ & Municipal & $0-10$ & $\begin{array}{c}\mathrm{DF}\left(\mathrm{NaCl} 1.2 \mathrm{~g} \mathrm{~cm}^{3}, \mathrm{Nal}\right. \\
\left.1.6 \mathrm{~g} \mathrm{~cm}^{3}\right), \mathrm{H}_{2} \mathrm{O}_{2} \\
\end{array}$ & LM, FTIR & Diverse & NA & $310(0-2760)$ & $\begin{array}{c}>60 \\
\text { Mainly 500-3000 }\end{array}$ & frag, fib>films & Zhou et al. (2020) \\
\hline $\begin{array}{c}\text { Ithaca (USA) } \\
\text { Cobleskill (USA) }\end{array}$ & $\begin{array}{l}1 \\
3\end{array}$ & $\begin{array}{l}\text { orch } \\
\text { NA }\end{array}$ & $\begin{array}{l}\text { Sew } \\
\text { Sew }\end{array}$ & Municipal & $\begin{array}{c}0-10,10-25,25- \\
50\end{array}$ & S-DF (water) & LM & NA & NA & $\begin{array}{l}1250 \pm 60 \\
1240 \pm 87\end{array}$ & NA & fib & Zubris and Richards (2005) \\
\hline
\end{tabular}

$1.5 \mathrm{~g} \mathrm{~cm}^{-3}$ and a subsequent oxidation of soil organic matter (SOM). Subsequent LM and FTIR showed concentrations of $2131 \pm 371$ items of polyethylene (PE), polyethylene terephthalate (PET), polypropylene (PP), polystyrene (PS) and polyvinyl chloride (PVC) per kilogram of dry soil, mainly in the shape of fibers and fragments. Very similarly, Zhang and Liu (2018) sampled polymers from four agricultural sites with plastic greenhousing, sewage sludge and wastewater application and from one recently untreated afforested site near Kunming. Using the oxidation of SOM and DF at $1.8 \mathrm{~g} \mathrm{~cm}^{-3}$, they found average concentra- tions of 26070 items $\mathrm{kg}^{-1}(\min -13470$ items kg-1 ; max 42960 items kg ${ }^{-1}$ ) in farmland Gleysols, 12050 items kg ${ }^{-1}$ ( $\min -7100$ items kg ${ }^{-1}$; $\max -26630$ items kg-1 ) in farmland Nitisols and 14440 items kg ${ }^{-1}$ (min -8180 items kg-1

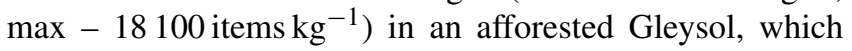
indicates both the plastic load and the soil type to be factors of MP concentrations in soils. About $82 \%$ of the found items had sizes $<250 \mu \mathrm{m}$, and fibers were the predominant shape, pointing out that this part came from wastewater origin. Much higher concentrations were found by Zhou et al. (2019), who extracted plastic from urban fallows (min - 
22000 items $\mathrm{kg}^{-1}$; $\max -200000$ items $\mathrm{kg}^{-1}$ ), horticulture $\left(\min -43000\right.$ items kg${ }^{-1} ; \max -620000$ items kg${ }^{-1}$ ) and

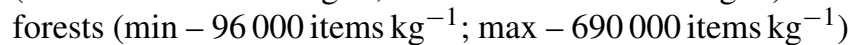
using a similar method with a cut-off at $1.55 \mathrm{~g} \mathrm{~cm}^{-3}$. The samples largely originated from sites near industrial areas in Wuhan.

A total of five studies with 90 sites examined the influence of plastic mulching and plastic greenhousing on MP concentrations in agricultural, horticultural and orchard plots (Liu et al., 2018; Zhang et al., 2018; Huang et al., 2020; Zhang et al., 2020; Zhou et al., 2020). In Shihezi, Huang et al. (2020) fractionated MPs from cotton fields at $1.85 \mathrm{~g} \mathrm{~cm}^{-1}$, with subsequent $\mathrm{H}_{2} \mathrm{O}_{2}$ treatment. Concentrations measured by using LM and FTIR increased with the continuing application of plastic mulching from $80 \pm 49$ ( 5 years) to $308 \pm 138$ (15 years) and $1076 \pm 347$ items kg $^{-1}$ ( 24 years). The exponential increase in particle numbers could be explained by intensified mulching or comminution of MPs over time. By using a similar method with a density cut-off at $1.6 \mathrm{~g} \mathrm{~cm}^{-3}$, Zhou et al. (2020) quantified MPs from 60 agricultural sites around Hangzhou Bay. Average concentrations were

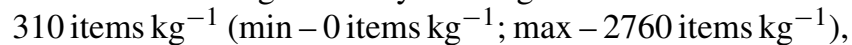
and counts in areas with plastic mulching were more than twice as high as in those without. Unlike these two, Liu et al. (2018) used a lower density cut-off of $1.2 \mathrm{~g} \mathrm{~cm}^{-3}$ to measure low-density MPs in 20 plastic-mulched horticulture near Shanghai, with $54.3 \%$ of the items $<1000 \mu$ m, mainly fibershaped, and concentrations of only $70 \pm 13$ items kg${ }^{-1}$. Due to the high number of sites with low concentrations pooled in Liu et al. (2018) and Zhou et al (2020), the actual average field concentration of MPs is lower than calculated in this review.

The only East Asian studies that examined item and mass concentrations took place in rural sites on the northern Chinese loess plateau (Zhang et al., 2018) and the city of Harbin (Zhang et al., 2020). Both used distilled water for the extraction of light density MPs. About $80 \pm 136,87 \pm 213$ and $187 \pm 222$ items kg ${ }^{-1}$ were measured on an agricultural field with plastic mulching and horticultural and orchard fields without plastic mulching (Zhang et al., 2018). Similar concentrations were found in rural and municipal areas near Harbin (Zhang et al., 2020). Both studies distinguished MPs from other particles by using an innovative melting method and a shape-to-mass model to derive mass concentrations from particle sizes $\left(n=7\right.$; median $-0.1 \mathrm{mg} \mathrm{kg}^{-1} ; 25 \%-$ $\left.0.0 \mathrm{mg} \mathrm{kg}^{-1} ; 75 \%-0.4 \mathrm{mg} \mathrm{kg}^{-1}\right)$. Additionally, surfaces of $6.2 \pm 23.4$ and $1.7 \pm 2.9 \mathrm{~mm}^{2} \mathrm{~kg}^{-1}$ were measured microscopically in municipal and rural samples, respectively (Zhang et al., 2020). The predominance of fibers in Liu et al. (2018) and Zhou et al. (2020) further suggests that past or present application of sewage sludge or waste waters could not be ruled out for these sites.

Soils along busy roads are exposed to contamination with particles originating from road and tire wear. Around 1142 items kg ${ }^{-1} \quad\left(n=12\right.$; $\min -300$ items kg ${ }^{-1}$; $\max -$
12500 items $\mathrm{kg}^{-1}$ ) were found in the vicinity of suburban roads in the municipal area of Wuhan Chen et al. (2020). This is the only study on traffic-derived soil MPs in China and is among only two studies worldwide.

In a globally unique sampling, Lv et al. (2019) investigated ponding as an entry pathway of MPs to rice cultures. The respective concentrations in paddy fields with and without rice-fish cocultures, often used as systems of production in Southeast Asia, were very low (up to $18 \pm 6$ items kg-1) between the rice-planting periods and more than twice as high in the planting season when the fields are ponded. Since the use of fresh water for irrigation represents a neglected entry pathway into agricultural soils, future investigation is needed with regards to how soil MP concentration is affected by the amount of irrigated water, its MP load and the flooding regime.

Throughout the Chinese studies, four contained data on soils without statements on the origin of MPs (NA). These samplings comprised very different sites such as the Nankai University campus in Tianjin (Han et al., 2019), horticulture in the vicinity of the Wuhan municipal area (Chen et al., 2020), an afforested rural area near Kunming (Zhang and Liu, 2018) and both a rural horticultural site and a orchard on the loess plateau (Zhang et al., 2018). These sites contained $118 \pm 190$ items kg ${ }^{-1}$ and $0.3 \pm 0.4 \mathrm{mg} \mathrm{kg}^{-1}(n=3)$ in rural areas and 1142 items kg$)^{-1}\left(n=10 ; 25 \%-938\right.$ items kg$~^{-1}$; $75 \%-4423$ items kg${ }^{-1}$ ) in municipal areas. Moreover, there are no studies on areas with littering, the application of composts or digestates, only sewage sludge application or without any contamination.

\subsection{Europe}

Taking a look at the European continent, we see fewer studies with more heterogeneous loads and a focus on MP origins different from those in China. The average concentrations amount to 2914 items kg-1 $\left(n=30 ; 25 \%\right.$ - 1332 items kg ${ }^{-1}$; $75 \%-8159$ items kg$\left.{ }^{-1}\right)$ and $8.9 \mathrm{mg} \mathrm{kg}^{-1}(n=6 ; 25 \%-$ $\left.0.3 \mathrm{mg} \mathrm{kg}^{-1} ; 75 \%-381.3 \mathrm{mg} \mathrm{kg}^{-1}\right)$ and are twice as high as in China.

Three studies with a total of 14 sites focus on the application of sewage sludge in farmland soils. They each used DF at $1.7 \mathrm{~g} \mathrm{~cm}^{-3}$, followed by LM and FTIR analysis, but different pretreatments with either $\mathrm{H}_{2} \mathrm{O}_{2}$ plus enzymes, detergents or no handling (Vollertsen and Hansen, 2017; Ljung et al., 2018; van den Berg et al., 2020). On croplands that were largely located in rural areas of the province of Valencia (Spain) and received an annual sludge application, the MP concentrations increased, on average, threefold within 10 years of application (van den Berg et al., 2020), a rate that is in the range of Huang et al. (2020). The fields contained an average particle number of 3330 items kg ${ }^{-1}$ (min - 999 items kg-1; max -8658 items $\mathrm{kg}^{-1}$ ), whereas on untreated control plots only one-third was counted. These values are 1 to 3 orders of magnitude lower than those found by Vollertsen and Hansen 
(2017) in a Danish farmland soil, which contained on average 71000 items $\mathrm{kg}^{-1}$ (mainly PE, PP and nylon) on sites with sludge application and more than twice as much on the control site. Both studies, however, published concentrations equivalent to those in the Chinese studies.

Vollertsen and Hansen (2017) also estimated mass concentrations of $5.8 \mathrm{mg} \mathrm{kg}^{-1}$ ( $\mathrm{min}-0.0 \mathrm{mg} \mathrm{kg}^{-1}$; $\max -$ $16.5 \mathrm{mg} \mathrm{kg}^{-1}$ ) after sludge application and $12.0 \mathrm{mg} \mathrm{kg}^{-1}$ $\left(\min -0.1 \mathrm{mg} \mathrm{kg}^{-1} ; \max -224.3 \mathrm{mg} \mathrm{kg}^{-1}\right.$ ) on the control soil by use of a shape-to-mass model (Simon et al., 2018). These data largely correspond to other soils with low contamination. Due to issues with the analysis, the author suggested that the data should be viewed as preliminary results. With a similar method, Ljung et al. (2018) calculated mass concentrations from LM images and identified MP concentrations of $0.3,0.3$ and $3.4 \mathrm{mg} \mathrm{kg}^{-1}$ near Malmö (Sweden), that have been amended with singular 0,1 and $3 \mathrm{t}$ sewage sludge $\mathrm{ha}^{-1} \mathrm{a}^{-1}$, respectively.

The only available European study on road dust was conducted by Dierkes et al. (2019). The authors used a pressurized liquid extraction (PLE) in combination with pyrolysisgas chromatography-mass spectroscopy (Pyr-GC-MS) for the extraction and quantification of PE, PP and PS from soil sampled adjacent to an arterial road near Köln (Cologne, Germany). Mass concentrations found in this study (915 \pm $63 \mathrm{mg} \mathrm{kg}^{-1}$ ) overshoot values measured in farmland soils by far and are more similar to industrial sides (Fuller and Gautam, 2016).

Without the specification of entry pathways, extremely high particle counts were found in German and Austrian soils by $\mathrm{LM}$ after extraction with preliminary $\mathrm{H}_{2} \mathrm{O}_{2}$ treatment and ultrasonication (U) plus density fractionation (DF) at $1.45 \mathrm{~g} \mathrm{~cm}^{-3}$ (Meixner et al., 2020). The method for manual LM counting included the support by an MP image reference database to identify items $>5 \mu \mathrm{m}$. The extrapolated concentrations of $11 \times 10^{6}$ items kg${ }^{-1}$ (min $-2 \times 10^{6}$ items kg ${ }^{-1}$; $\max -26 \times 10^{6}$ items kg-1) exceed values of other studies by 2 to 4 orders of magnitude.

The only study worldwide that has worked on an uncontaminated site was conducted on a conventional farmland in southern Germany with no plastic mulching or application of sewage sludge in advance (Piehl et al., 2018). The authors found very low concentrations of mainly films and fragments of PE, PP and PS. However, it is difficult to distinguish whether the low counts of 0.31 items kg-1 are caused by the low human input or the method of extraction. Only particles $>1000 \mu \mathrm{m}$ were extracted by picking from $\mathrm{H}_{2} \mathrm{O}_{2}$-treated and sieved soil. Thus, smaller MPs are ignored, which represent the majority of MPs (Huerta Lwanga et al., 2017; Liu et al., 2018; Zhang and Liu, 2018; Rezaei et al., 2019; Zhou et al., 2019; Chen et al., 2020; Ding et al., 2020). In addition, no further studies were conducted in Europe with a focus on mixed contamination, plastic mulching, littering, ponding or the application of composts or digestates. Nearly no data on the shape and size of collected MPs were recorded.

\subsection{The Americas}

A total of three out of four pan-American studies focused on sewage sludge application and found fibers more than other shapes (Zubris and Richards, 2005; Corradini et al., 2019; Crossman et al., 2020). All sites contained, on average, 1190 items kg ${ }^{-1}\left(n=37 ; 25 \%-286\right.$ items kg ${ }^{-1} ; 75 \%-$ 2060 items kg ${ }^{-1}$ ), with the lowest concentrations in Ontario (Canada). Here, agricultural landscapes received repeated applications of sludge and were examined by use of DF and LM and FTIR (Crossman et al., 2020). The MP concentrations increased from 4 items kg-1 on a site with no appli-

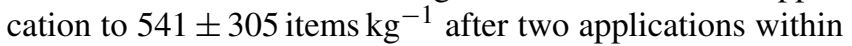
5 years. Zubris and Richards (2005) extracted MP from four sites in the state of New York (USA), with DF in the water and quantified only fibers by polarized LM. The authors found about 1235 items kg-1 (min - 370 items kg-1 ${ }^{-1}$ max 2060 items kg $^{-1}$ ), which is in an order of magnitude like in global soils with sewage sludge application. A comparison with zones of preferential flow shows an enhanced transport of MP fibers through macropores.

A comprehensive work conducted on agricultural land in the vicinity of Melipilla, Región Metropolitana de Santiago (Chile), reported very similar concentrations (Corradini et al., 2019). During 5 years, dewatered sewage sludge from a communal wastewater treatment plant was applied 1-5 times with an annual rhythm and amount of $40 \mathrm{tha}^{-1}$, an usual amendment. After the end of application in the year 2017, concentrations ranged from 1200 items kg ${ }^{-1}$ (min 0 items $\mathrm{kg}^{-1} ; \max -2200$ items $\mathrm{kg}^{-1}$ ) in plots with one application to 3600 items kg-1 (min - 1000 to 10200 items kg${ }^{-1}$ ) after five applications. In addition, the authors used a shapeto-mass model to estimate mass concentrations between 1.4 and $4.4 \mathrm{mg} \mathrm{kg}^{-1}$.

In a worldwide unique study, Huerta Lwanga et al. (2017) quantified littered MPs in rural gardens on the Yucatán Peninsula (Mexico). The team extracted low-density MPs by using $\mathrm{U}$ and DF in distilled water. About $95 \%$ of the extracted plastic had a size of $<50 \mu \mathrm{m}$ and, in total, amounts of $870 \pm 1900$ items kg-1. By using a denser separation medium, the actual values might have been higher due to the additional yield of denser plastics.

\subsection{Middle East}

In order to explore the translocation of soil MPs by wind erosion, Rezaei et al. (2019) measured the concentration of lowdensity MPs in soils of the (semi-)arid Fars province (Iran). Using a flotation method for the extraction of low-density MPs in the water (Zhang et al., 2018) and LM, 1.2 \pm 0.6 and $205 \pm 186 \mathrm{mg} \mathrm{kg}^{-1}$ were detected at five agricultural sites and only $0.2 \pm 0.1 \mathrm{mg} \mathrm{kg}^{-1}$ and $38 \pm 17$ items kg${ }^{-1}$ on rangelands. Inadequate removal of plastic mulch films was assumed to be the main origin of MPs in these areas. 


\subsection{Australia}

Fuller and Gautam (2016) used a pressurized fluid extraction (PFE) method, in combination with gravimetric quantification and identification by FTIR, to measure different plastics $<1 \mathrm{~mm}$ in soils near an industrial facility in Sydney (Australia). In accordance with the high potential of contamination on industrial sites, which was also found by Zhou et al. (2019), the recorded $2400 \mathrm{mg} \mathrm{kg}^{-1}$ ( $\mathrm{min}-300 \mathrm{mg} \mathrm{kg}^{-1}$; $\max$ $-67500 \mathrm{mg} \mathrm{kg}^{-1}$ ) must be referred to as highly contaminated.

\section{Global data assessment}

\subsection{Applied methods}

The majority of the studies in the present work recorded data in items per kilogram (20 studies with 218 sites); eight studies contained data in milligrams per kilogram on 29 sites and one study with four sites in square millimeters per kilogram. A total of five studies collected both number and mass concentrations of 24 sites in total, where one applied all three measures.

The most commonly used method thereby comprised a treatment step to oxidize or detach soil organic matter in advance (in seven cases) or subsequently (six) to a mechanical agitation followed by DF, LM counting and identification by use of FTIR (13) or Raman spectroscopy (two). The treatment was conducted in different combinations by using $\mathrm{H}_{2} \mathrm{O}_{2}$ (10), Fenton's reaction, $\mathrm{NaOH}, \mathrm{KOH} / \mathrm{NaClO}$, enzymes or detergents (each one) and is lacking in eight cases. Physical stressing of the soil matrix was performed by stirring/shaking eight times, ultrasonication (four), both (three) and bubbling (one), whereas any agitation lacks in five studies. A total of 11 studies used a density cut-off $\geq 1.5 \mathrm{~g} \mathrm{~cm}^{-3}$ to extract a collective of the most common types of plastic, whereas nine studies applied less dense extraction media. In conclusion, physical agitation and oxidation of organic matter, together with fractionation in a dense aqueous solution is the scheme most often used in advance for optical analysis of soil MPs.

A total of six studies additionally applied a shape-to-mass model to estimate soil MP masses, and two studies measured MP masses directly from soil samples by using PFE plus Pyr-GC-MS or PFE plus weighing. The TED-GC-MS, also listed in Bläsing and Amelung (2018) as an adequate measurement method, has not been applied to quantify soil MPs in the present field studies.

\subsection{Global concentrations}

Throughout all 223 examined sampling sites, the medians of soil MPs are 1167 items kg-1 $(n=218 ; 25 \%-$ 89 items kg-1; $75 \%-2870$ items kg ${ }^{-1}$ ) and $0.6 \mathrm{mg} \mathrm{kg}^{-1}$ $\left(n=29 ; 0.004,2.65 \mathrm{mg} \mathrm{kg}^{-1}\right)$. Some studies in parts conducted on industrial areas exceed these values by orders of magnitude (Fuller and Gautam, 2016; Vollertsen and Hansen, 2017; Dierkes et al., 2019; Zhou et al., 2019; Meixner et al., 2020). In the following, global data are pooled according to entry pathways, land use and vicinity (Fig. 3).

The sites with sewage sludge application have average MP concentrations of 1998 items kg-1 $^{-1}(n=24 ; 25 \%$ - 999 items kg-1; $75 \%$ - 3616 items kg ${ }^{-1}$ ) or $2.2 \mathrm{mg} \mathrm{kg}^{-1}$ $\left(n=8 ; 1.7,4.5 \mathrm{mg} \mathrm{kg}^{-1}\right)$, which increase with the number of sewage sludge applications (Corradini et al., 2019; Crossman et al., 2020; van den Berg et al., 2020). These loads are approximately 1 order of magnitude above the values measured in fields with plastic mulching, both in terms of number and weight. According to medians and quantile ranges of item numbers, sites with the input of road dust and littering are similar to sludge sites. However, just like paddy fields and uncontaminated plots, these data sets are only based on one study with a few sampling sites, and the data of mass concentrations are even sparser.

The number of MP items in fields with agriculture and horticulture/orchards is well investigated, which is in contrast to grassland, fallow and forest soils. Both have similar average concentrations of about 1200 items kg-1 $(n=118$;

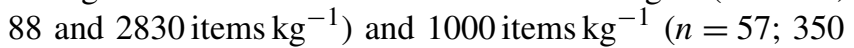
and 1604 items $\mathrm{kg}^{-1}$ ), but in agricultural landscapes, one encounters a much wider range of concentrations. A robust set of mass concentrations is only found in agricultural soils and amounts to average concentrations of $1.7 \mathrm{mg} \mathrm{kg}^{-1} \quad(n=20$; 0.3 and $2.8 \mathrm{mg} \mathrm{kg}^{-1}$ ). All other land uses have a minor number of studies and sampling sites.

Sites in the vicinity of municipal areas are investigated three times more often than rural areas. With 1275 items kg-1 $\left(n=147 ; 316\right.$ and 3005 items kg$\left.{ }^{-1}\right)$ compared to 187 items kg-1 ( $n=39 ; 0.3$ and 1332 items kg ${ }^{-1}$ ), the municipal measurements result in a particle number that is about 1 order of magnitude larger than in rural areas. This relation is also found in terms of MP masses that amount to $2.1 \mathrm{mg} \mathrm{kg}^{-1}\left(n=11 ; 0.7\right.$ and $\left.4.5 \mathrm{mg} \mathrm{kg}^{-1}\right)$ and $0.2 \mathrm{mg} \mathrm{kg}^{-1}$ $\left(n=15 ; 0.0\right.$ and $0.7 \mathrm{mg} \mathrm{kg}^{-1}$ ), respectively. This implies a positive relation between population density and plastic concentration, which was also shown along a river shore in Mongolia (Battulga et al., 2019). However, in some world regions, rural and urban areas overlap, especially in China, where suburban areas contain large agricultural sites and rural areas are often densely inhabited, leading to more similar concentrations in both vicinities. Measurements in highly contaminated industrial areas, although conducted only a few times, indicate concentrations that are 2 to 4 orders of magnitude above nonindustrial areas.

In conclusion, the most comprehensive data on both item number and mass are given for plastic mulching, sewage sludge application and multiple MP inputs as well as municipal and rural areas with food production. Based on overlapping interquartile ranges, the common concentrations in the respective categories range between $<1$ and 12760 items kg $^{-1}$ in dry soil and 0 and $4.5 \mathrm{mg} \mathrm{kg}^{-1}$ dry soil. 
(a)
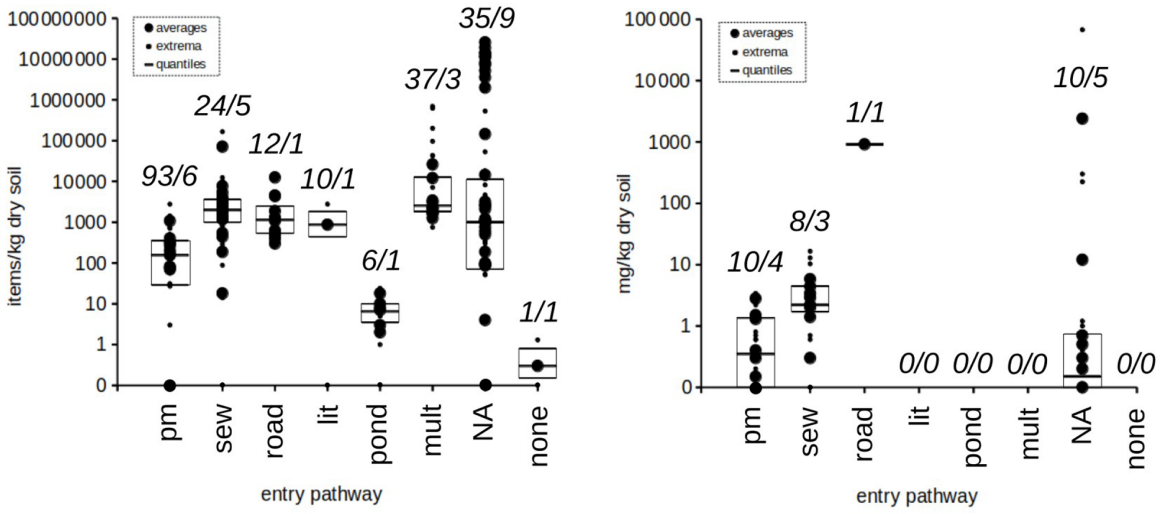

(b)
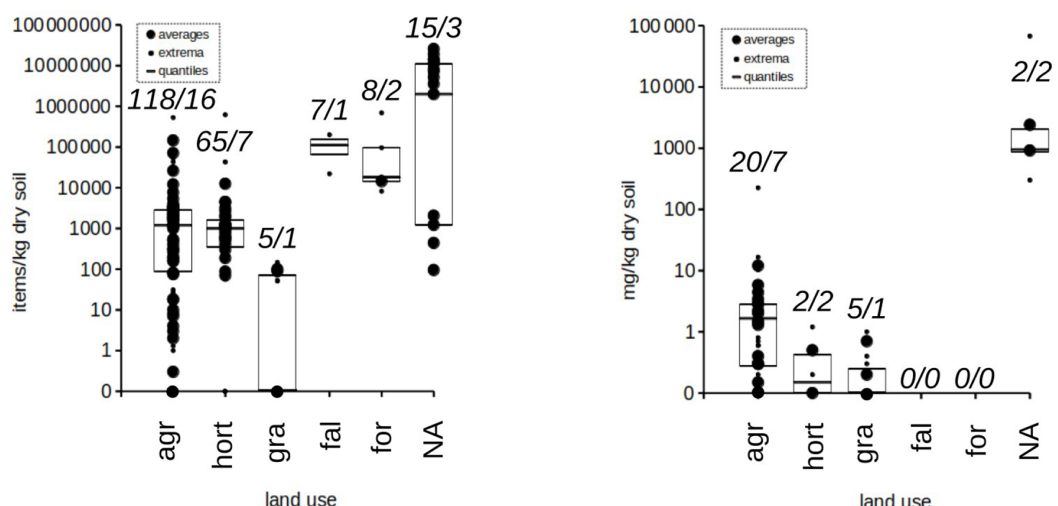

(c)
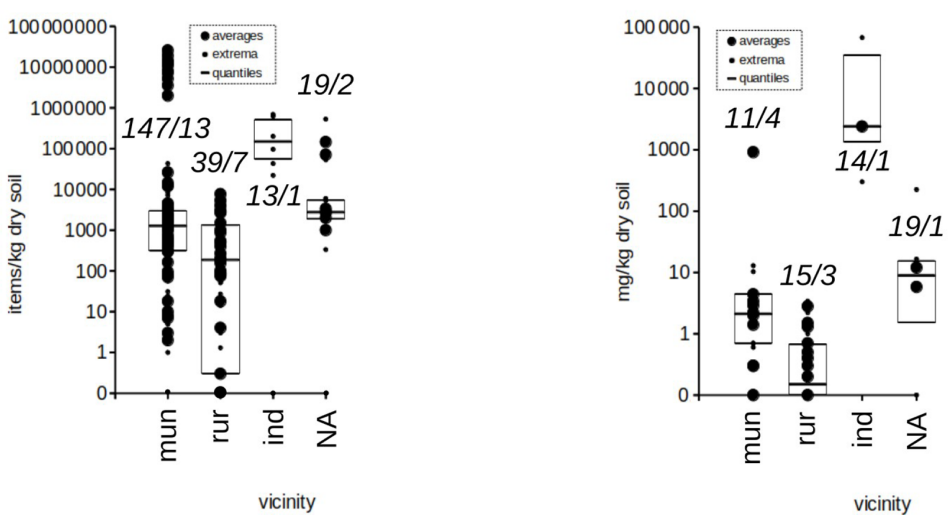

Figure 3. Concentrations of microplastics in soil ecosystems. Big dots mark median and mean concentrations measured in worldwide field experiments, small dots are the related extreme values or standard deviations, thick horizontal lines are the overall medians and narrow lines are the $25 \%$ and $75 \%$ quantile. Italicized numbers indicate the underlying number of sampling sites or studies. (a) Entry pathways are denoted as follows: pm - plastic mulching and plastic greenhousing; sew - sewage sludge and waste water application; road - road and tire wear; lit - littering; pond - ponding; mult - multiple; none - no existing entry pathways. (b) Land uses are denoted as follows: agr agriculture; hort - horticulture and orchards; gra - grassland; fal - fallow; for - forest. (c) Vicinities of the sampling sites are denoted as follows: mun - municipal; rur - rural; ind - industrial. NA indicates data with no specification. No data were found on compost and digestate application, landfill soils or wilderness).

In most cases extreme values do not scatter more widely than the medians, leading to the assumption that we are faced to a wide and even distribution of natural soil MP concentrations. Measurements with larger sets of separated sites, for example, in the frame of national monitoring programs, will allow the estimation of more precise and localized values of soil microplastic contamination. Other data sets, like on tire wear, forests, littering or industrial areas, are sparse and might only give indications of expectable concentrations. In no region were studies on the application of MPs through 
composts and digestates conducted. Also, the contamination of wilderness soils was not in the focus of recent research on MP. In contrast, NA data were numerous in most categories due to a lack of comprehensive documentation.

\subsection{How robust are these data?}

In this work, 23 studies with, in total, 223 sampling sites were evaluated in terms of the entry pathways of MPs to soils, the underlying land use and the vicinity of the investigated sites. Particularly in China, a large number of similarly structured studies provided a first spatial overview of common concentrations. Despite this satisfying yield of data, our synopsis on MP concentrations in global soils must, however, be interpreted under certain restrictions.

In about $84 \%$ of the sites, at least one MP entry pathway has been described and analyzed, whereas no information on origins (NA) was given on the remaining sites. However, further possible sources for MP inputs have neither been ruled out nor quantified in any study. For instance, the background pollution due to eolian deposition can be assumed to be ubiquitous even in remote global regions (Dris et al., 2016; Allen et al., 2019; Evangeliou et al., 2020). Rezaei et al. (2019) found $0.2 \pm 0.1 \mathrm{mg} \mathrm{kg}^{-1}$ and $38 \pm 17$ items kg $^{-1}$ related to air transport in sparsely populated grassland areas. Throughout the world, the deposed MP concentrations most likely decrease towards more remote areas, but are widely unknown. Along roads, there is also a contamination of soils with tire wear, due to runoff, but also from windblown dispersal that results in as yet unknown spatial concentration gradients (Dierkes et al. 2019). Last, but not least, littering produces a series of locally randomized point loads, which increasingly appear in the vicinity of urban areas, because most of the end-user waste is produced there. Those diffuse MP sources were hardly addressed within the reviewed papers and appear unnoticed in addition to the entry pathways the studies focused on. Thus, their contribution to the total load is likewise an unnamed part of the measured values. This results in an unknown overestimation of the loads coming in the focused entry pathways. Some of the studies additionally provide information, for example, that other entry pathways typically appear in their region, like irrigation with river water, use of mulch foils or the application of sewage sludge or waste water, but do not provide past and present information on their application on the measured plots. As a consequence, the classification of MP inputs can be improved by differentiated data on entry pathways and the consequent inclusion of historical plot data.

Sparsely applied within the reviewed works, basic soil characterization is still an integral part of the description of sampling sites. Only $15 \%$ of the sites are described sufficiently by means of soil texture or soil type in terms of the World Reference Base (WRB) or US soil taxonomy. First data on Gleysols and Nitisols, which imply that the soil type can influence the accumulation of MPs in a way directly or indirectly (Zhang and Liu, 2018), show that standardized characterization of the soils will be helpful in future studies to relate the MP load with soil properties. Data on further parameters, such as soil carbon content and micro- and macrofaunal activity, that are found to affect the aggregation, transport, comminution and decay of microplastics (Büks et al., 2020a) are largely missing.

At most sites (81\%), the sampling depths are well documented and vary between the top $5 \mathrm{~cm}$, parts of the topsoil, the plow layer or deeper layers (Piehl et al., 2018; Zhang et al., 2018; Huang et al., 2020). As the MP concentration is shown to vary with depth (Zubris and Richards, 2005; Liu et al., 2018; Zhang et al., 2018; Crossman et al., 2020), projecting concentrations of certain upper parts of a top layer to predict the total top layer's concentration will result in an overestimation of its MP stock. This might be less important in agricultural soils with annually plowed topsoils but will affect the concentrations estimated in soils with no tillage. As a consequence, a documentation of the plowing regime and a gradual and/or mixed sampling of the topsoil is strongly recommended. Furthermore, samplings in subsoils could give important information on the vertical translocation of MPs towards the groundwater layer.

Organic matter is assumed to interfere with the measurements by binding plastic particles to the mineral matrix during the extraction or being mistaken with plastic in the following microscopic examination. This could influence the yield of extraction, and later identification, of MP. For this reason, different pre- and post-treatments with $\mathrm{H}_{2} \mathrm{O}_{2}$ or other agents were applied in several studies. Reviewed data showed that, on average, $\sim 10 \times$ more particles were extracted by using a pretreatment compared to no treatment or post-treatment (Fig. 4). This difference is also found in data generated by using shape-to-mass models and is not affected by the extreme high values found by Meixner et al. (2020).

The total yield and composition of the extracted MPs also strongly depends on the applied density cut-off. Some studies focused on a certain type of plastic, such as light-density MPs translocated by wind (Rezaei et al., 2019), or fragmented PE foil, that was used for plastic mulching (Liu et al., 2018). Therefore, these studies used a less dense fractionation medium $\left(\leq 1.2 \mathrm{~g} \mathrm{~cm}^{-3}\right)$ and excluded denser MPs from their measurements. In different terrestrial environments, low-density plastics like PE and PP were found to be much more abundant than denser materials such as PU, PET and PVC (Büks et al., 2020a). The great majority of studies that used dense solutions with $\rho \geq 1.2 \mathrm{~g} \mathrm{~cm}^{-3}$ therefore extracted large parts of soil plastic independently from the chosen density cut-offs, leading to trustworthy orders of magnitude. However, only density cut-offs $\geq 1.5 \mathrm{~g} \mathrm{~cm}^{-3}$ are suitable for extracting nearly all types of plastic with relevant global production output (with the exception of chlorinated PVC and PTFE). On the other hand, densities $\geq 1.6 \mathrm{~g} \mathrm{~cm}^{-3}$ cause the coextraction of parts of the mineral matrix (Cerli et al., 2012). As a consequence, the application of a density cut- 


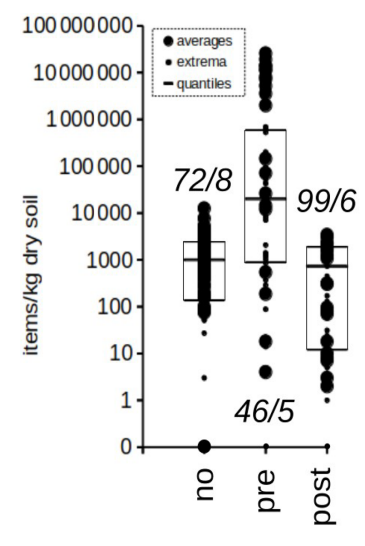

treatment

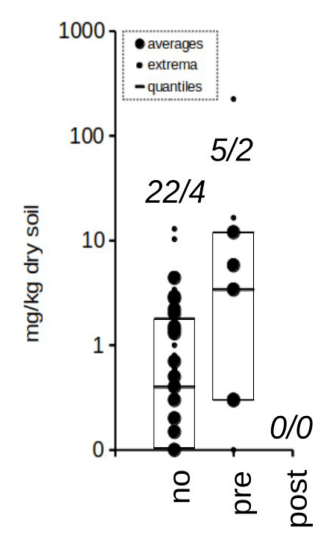

treatment
Figure 4. Quantities of MPs measured after density fractionation without the treatment of soil organic matter (SOM; no), with pretreatment (pre) and post-treatment (post). Big dots mark median and mean concentrations measured in worldwide field experiments, small dots are the related extreme values or standard deviations, and strong horizontal lines are the overall medians and narrow lines are the $25 \%$ and $75 \%$ quantile. Italicized numbers indicate the underlying number of sampling sites or studies.

off of $1.6 \mathrm{~g} \mathrm{~cm}^{-3}$, like in soil carbon pool analyses, is recommended to avoid underestimation of the soil MP pool (Kaiser and Berhe, 2014). For such density cut-offs, sodium polytungstate (SPT) is an expansive but appropriate fractionation medium as it can be adjusted to a wide range of densities (1.0 to $3.1 \mathrm{~g} \mathrm{~cm}^{-3}$ ), is non-toxic, is environmentally sound and is recyclable ( $\mathrm{Six}$ et al., 1999). Saturated $\mathrm{NaCl}$ solution, in contrast, only has a maximum density of $1.2 \mathrm{~g} \mathrm{~cm}^{-3}$, whereas $\mathrm{ZnCl}_{2}$ and $\mathrm{NaI}$ are categorized as dangerous for the environment.

After density fractionation, the MPs are often separated from the dense solution by use of a fine-pored metal screen and cleaned by rinsing at the same place. To our knowledge, the smallest available mesh aperture is, to date, $>5 \mu \mathrm{m}$ (optimized Dutch weave; GKD Group). Items with a profile smaller than this might become lost during the extraction. To date, we do not know anything about the contribution of this fraction exactly due to this filtration problem. However, adverse effects on manifold parts of the soil fauna have shown to increase with decreasing MP particle size and irregular shape (Büks et al., 2020a; Büks et al., 2020b), which emphasizes the importance of small MP and nanoplastic analytics. In the reviewed studies, large percentages of items $<250 \mu \mathrm{m}$ were extracted independent of the entry pathway (Table 1). The application of manual counting and the lack of defined lower size limits for counting cause imprecise quantification of this small MP fraction. Automated counting combined with particle sizing and shape analysis is therefore a coming challenge in MP analytics.

Not only the extraction but also the identification of MP types is crucial for the estimation of their respective quanti- ties in soil. Of the 11 studies that used an appropriate density cut-off $\geq 1.5 \mathrm{~g} \mathrm{~cm}^{-3}$, only two analyzed a broad set of common plastics. A total of two further studies used less dense extraction media or direct extraction by using PFE in advance to analyze a similar spectrum of plastics, while all other studies tested $\leq 4$ plastic types or lacked any characterization in this category. For a better comparability of studies, we suggest measuring a broad set of commonly produced MPs by default plus other plastics with respect to the particular research.

The PFE method was only applied two times among the reviewed studies and showed values 3 orders of magnitude above all other mass values compiled by use of shape-tomass models (Fuller and Gautam, 2016; Dierkes et al., 2019). It is unclear to what extent this is caused by the selection of sampling sites, which are located within an industrial area and right next to an arterial road, or whether it is due to a significant mass fraction that has so far been ignored by optical methods but has been captured by PFE. At this stage, this cannot be estimated due to a small number of sites and the lack of comparative experiments between both the PFE and methods based on density fractionation.

Given data show that sites with sewage sludge application have mass concentrations similar to those with plastic mulching but 10 times higher item concentrations (Corradini et al., 2019; Rezaei et al., 2019). This points to smaller particle sizes in sewage sludge, which could be related to fibers (e.g., originating from textile cleaning), that appear more pronounced on sites with sewage sludge application (Table 1). That could mean that the size characteristics of extracted particle collectives are strongly related to their entry pathways so that we can estimate masses ex post from given data of item numbers. The relationship of items and mass concentrations from data sets with both measures shows a different linear increase in soils with sewage sludge application $\left(R^{2}=0.99\right.$; Corradini et al., 2019) and those with plastic mulching $\left(R^{2}=0.67\right.$; Zhang et al., 2018, 2020; Rezaei et al., 2019; Fig. 5). This pattern is only based on shape-tomass data and is broken by the high concentrations found by Vollertsen and Hansen (2017). However, within the concentration range found to be common in soils $\left(<4.5 \mathrm{mg} \mathrm{kg}^{-1}\right.$ and $<12760$ items kg${ }^{-1}$ ), the two trends imply that the MP input from mulching films has a lower number of particles per mass than MPs from sewage sludge. Derived from this data, the mass and number of particles might be roughly estimated, if knowledge of the entry pathways exists. To support this statement, however, a larger amount of data is necessary.

In conclusion, most studies focused on item concentrations, some calculated masses by using a shape-to-mass model and only a few measured MP masses directly. This results in less mass data and especially a lack of data generated by mass spectroscopic methods. Number data, however, give a simple load indicator but no clear characterization about the soil MP load as the particle size distribution can vary strongly between different entry pathways and sites 
Table 2. Evaluation of procedural steps used for the extraction of microplastics from soil. Extraction methods, additional treatments and methods for measurement appear in various combinations. Their compatibility with given requirements is shown, based on the reviewed literature. Question marks indicate unknown performances, $\rho$ refers to the density cut-off in grams per cubic centimeter, OM refers to organic matter, PFE refers to pressurized fluid extraction, FTIR refers to Fourier transform infrared spectroscopy, Pyr-GC-MS refers to pyrolysis-gas chromatography-mass spectrometry and TED-GC-MS refers to thermal extraction and desorption-gas chromatography-mass spectrometry. StM refers to shape-to-mass model.

\begin{tabular}{|c|c|c|c|c|c|c|c|c|}
\hline & & $\begin{array}{l}\text { Increased } \\
\text { yield of } \\
\text { extraction }\end{array}$ & $\begin{array}{l}\text { Increased } \\
\text { co- } \\
\text { extraction } \\
\text { of OM }\end{array}$ & $\begin{array}{l}\text { Coextraction } \\
\text { of mineral } \\
\text { phase }\end{array}$ & $\begin{array}{l}\text { Determination } \\
\text { of item num- } \\
\text { ber, } \\
\text { size or shape }\end{array}$ & $\begin{array}{l}\text { Determination } \\
\text { of MP mass }\end{array}$ & $\begin{array}{l}\text { Determination } \\
\text { of plastic } \\
\text { types }\end{array}$ & $\begin{array}{l}\text { Determination } \\
\text { of MP } \\
\text { surfaces }\end{array}$ \\
\hline \multirow{2}{*}{$\begin{array}{l}\text { Oxidation of } \\
\text { natural OM }\end{array}$} & Pre-oxidation & Yes & $?$ & $?$ & Yes & Yes & Yes & $?$ \\
\hline & Post-oxidation & No & & & Yes & Yes & Yes & $?$ \\
\hline \multirow{3}{*}{$\begin{array}{l}\text { Extraction } \\
\text { method }\end{array}$} & Mechanical treatment & Yes & Yes & No & $?$ & Yes & Yes & $?$ \\
\hline & Density fractionation & $\geq 1.6$ & $\sim \rho$ & $>1.6$ & Yes & Yes & Yes & Yes \\
\hline & PFE & Yes & $?$ & No & No & Yes & Yes & No \\
\hline \multirow[t]{3}{*}{ Measurement } & Light microscopy & & & & Yes & StM & No & No \\
\hline & FTIR/Raman spectroscopy & & & & Yes & StM & Yes & No \\
\hline & Pyr-GC-MS/TED-GC-MS & & & & No & Yes & Yes & No \\
\hline
\end{tabular}

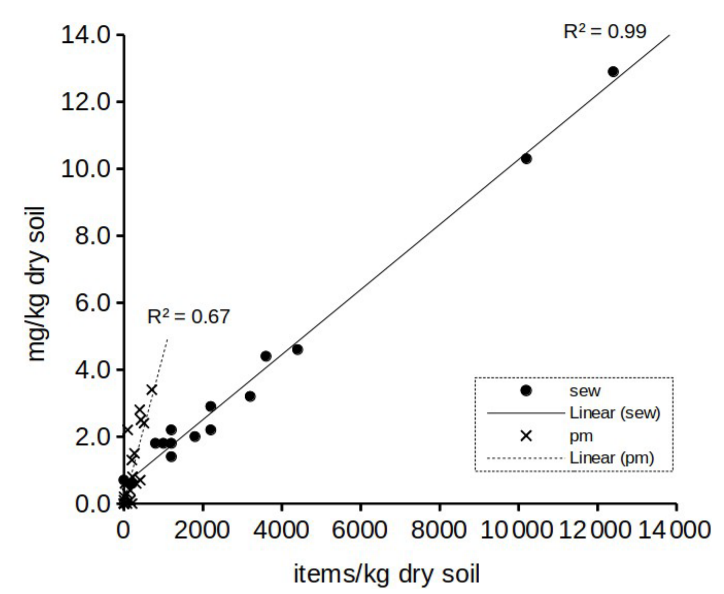

Figure 5. Regression of item and mass concentrations. Data were taken from sites with both measures $(n=38)$. Dots represent measurements in soils with sewage sludge application and crosses $(x)$ are those with plastic mulching. Linear trends are shown with lines.

(Table 1). Some of these studies therefore conducted a rough size classification, that address ecological relevant properties such as bioavailability and percolation. In combination with a valid shape-to-mass model, particle sizing might be a helpful tool for MP quantification in terms of both particle number and mass, especially in the case of low financial and methodical capabilities. An identification of the given plastic types can additionally be performed by using FTIR and Raman spectroscopy. The application of PFE, TED-GC/MS and $\mathrm{Pyr}-\mathrm{GC} / \mathrm{MS}$, which is promising for precise mass analytics, in turn eliminates information about the size and shape of the extracted plastic and, therefore, requires additional particle sizing. The compatibility of the underlying procedural steps with given requirements is listed in Table 2.
A measure, which is only applied once in the reviewed studies, is the concentration of MP surfaces (square millimeters per kilogram of dry soil). To date, little is known about the relationship of the specific surface of MP items to adverse effects on soil organisms, transportation and occlusion within the soil matrix. In future, experiments on soil contamination measurements of specific MP surfaces in soils could play an important role. Furthermore, upcoming research on soil MPs must not ignore plastic items $>5 \mathrm{~mm}$. Plastic mulching (and also littering) in particular causes the deposition of an amount of larger fragments (Ramos et al., 2015; Huang et al., 2020). Even if we entirely stop the MP input to global soil ecosystems, its weathering and comminution would be an important reserve pool that might lead to further increases in soil MP concentrations in future.

\section{Conclusions}

We reviewed 23 studies of soil MP concentrations with respect to the underlying entry pathways, land uses and vicinities. The, in total, 223 separated sampling sites were predominantly located in China and Europe. The studies largely focused on sewage sludge application and plastic mulching on agricultural and horticultural sites near cities and in the countryside. In contrast, research on industrial and natural areas, the inputs of MPs with road dust, littering, irrigation water, composts and digestates remain strongly underrepresented or are lacking overall. Common global MP concentration amounts are up to 13000 items kg-1 of dry soil and $4.5 \mathrm{mg} \mathrm{kg}^{-1}$ of dry soil, whereas concentrations on single plots exceeded these values. The mass and particle number introduced to global soils with sewage sludge is about 1 order of magnitude larger than with plastic mulching. According to other studies, the contamination in municipal vicinity is also 1 order of magnitude above that in rural areas, 
whereas concentrations in industrial areas overshoot this values by far. We recommend to using the common span to choose ranges of MP concentrations in future laboratory experiments. Field studies are suggested to further record soil characteristics, plot history and entry pathways and conduct a gradual and/or mixed sampling of the topsoil and a sampling of the subsoil. If density fractionation is used to extract MPs from soils, a $1.6 \mathrm{~g} \mathrm{~cm}^{-3}$ dense medium is strongly recommended for a sufficient separation of all common plastic types. A measurement of these types should be applied by default. Studies that determine particle numbers are invited to use particle sizing with a focus on the small-sized MP fractions that were shown to have significant influence on the health of soil organisms. We hope that these points can contribute to establishing a globally accepted pattern for soil microplastic measurements.

Data availability. All of the data are published within this paper and in the Supplement.

Supplement. The supplement related to this article is available online at: https://doi.org/10.5194/soil-6-649-2020-supplement.

Author contributions. FB developed the review concept, collected the data and prepared the paper. MK supervised the study by participating in structural discussions on the idea and concept of the paper and the final corrections.

Competing interests. The authors declare that they have no conflict of interest.

Acknowledgements. The authors extend their thanks to Esperanza Huerta-Lwanga, Fabio Corradini, Francisco Casado, Ines Fritz, Jes Vollertsen, Katharina Meixner, Mona Kubiczek, Pim van den Berg, Pablo Meza, Raúl Eguiluz and Violette Geissen for sharing their raw data.

Financial support. This open-access publication was funded by Technische Universität Berlin.

Review statement. This paper was edited by Raúl Zornoza and reviewed by two anonymous referees.

\section{References}

Allen, S., Allen, D., Phoenix, V. R., Le Roux, G., Jiménez, P. D., Simonneau, A., Binet, S., and Galop, D.: Atmospheric transport and deposition of microplastics in a remote mountain catchment, Nat. Geosci., 12, 339-344, https://doi.org/10.1038/s41561-0190335-5, 2019.

Barnes, D. K., Galgani, F., Thompson, R. C., and Barlaz, M.: Accumulation and fragmentation of plastic debris in global environments, Phil. Trans. R. Soc. B, 364, 1985-1998, https://doi.org/10.1098/rstb.2008.0205, 2009.

Battulga, B., Kawahigashi, M., and Oyuntsetseg, B.: Distribution and composition of plastic debris along the river shore in the Selenga River basin in Mongolia, Environ. Sci. Pollut. Res., 26, 14059-14072, https://doi.org/10.1007/s11356-019-04632-1, 2019.

Bläsing, M. and Amelung, W.: Plastics in soil: Analytical methods and possible sources, Sci. Total Environ., 612, 422-435, https://doi.org/10.1016/j.scitotenv.2017.08.086, 2018.

Büks, F., Loes van Schaik, N., and Kaupenjohann, M.: What do we know about how the terrestrial multicellular soil fauna reacts to microplastic?, SOIL, 6, 245-267, https://doi.org/10.5194/soil-6245-2020, 2020a.

Büks, F., van Schaik, N. L., and Kaupenjohann, M.: Mikroplastik aus Klärschlämmen hat das Potential Bodenleben zu schädigen, KW Korrespondenz Wasserwirtschaft, 9, 471-476, https://doi.org/10.3243/kwe2020.09.001, 2020 b.

Cerli, C., Celi, L., Kalbitz, K., Guggenberger, G., and Kaiser, K.: Separation of light and heavy organic matter fractions in soil - Testing for proper density cutoff and dispersion level, Geoderma, 170, 403-416, https://doi.org/10.1016/j.geoderma.2011.10.009, 2012.

Chen, Y., Leng, Y., Liu, X., and Wang, J.: Microplastic pollution in vegetable farmlands of suburb Wuhan, central China, Environ. Pollut., 257, 113449, https://doi.org/10.1016/j.envpol.2019.113449, 2020.

Corradini, F., Meza, P., Eguiluz, R., Casado, F., Huerta-Lwanga, E., and Geissen, V.: Evidence of microplastic accumulation in agricultural soils from sewage sludge disposal, Sci. Total Environ., 671, 411-420, https://doi.org/10.1016/j.scitotenv.2019.03.368, 2019.

Crossman, J., Hurley, R. R., Futter, M., and Nizzetto, L.: Transfer and transport of microplastics from biosolids to agricultural soils and the wider environment, Sci. Total Environ., 724, 138334, https://doi.org/10.1016/j.scitotenv.2020.138334, 2020.

de Souza Machado, A. A., Lau, C. W., Till, J., Kloas, W., Lehmann, A., Becker, R., and Rillig, M. C.: Impacts of microplastics on the soil biophysical environment, Environ. Sci. Technol., 52, 96569665, https://doi.org/10.1021/acs.est.8b02212, 2018.

Dierkes, G., Lauschke, T., Becher, S., Schumacher, H., Földi, C., and Ternes, T.: Quantification of microplastics in environmental samples via pressurized liquid extraction and pyrolysisgas chromatography, Anal. Bioanal. Chem., 411, 6959-6968, https://doi.org/10.1007/s00216-019-02066-9, 2019.

Ding, L., Zhang, S., Wang, X., Yang, X., Zhang, C., Qi, Y., and Guo, X.: The occurrence and distribution characteristics of microplastics in the agricultural soils of Shaanxi Province, in north-western China, Sci. Total Environ., 720, 137525, https://doi.org/10.1016/j.scitotenv.2020.137525, 2020. 
Dris, R., Gasperi, J., Saad, M., Mirande, C., and Tassin, B.: Synthetic fibers in atmospheric fallout: a source of microplastics in the environment? Marine Pollut. Bull., 104, 290-293, https://doi.org/10.1016/j.marpolbul.2016.01.006, 2016.

Eo, S., Hong, S. H., Song, Y. K., Lee, J., Lee, J., and Shim, W. J.: Abundance, composition, and distribution of microplastics larger than $20 \mu \mathrm{m}$ in sand beaches of South Korea, Environ. Pollut., 238, 894-902, https://doi.org/10.1016/j.envpol.2018.03.096, 2018.

Evangeliou, N., Grythe, H., Klimont, Z., Heyes, C., Eckhardt, S., Lopez-Aparicio, S., and Stohl, A.: Atmospheric transport is a major pathway of microplastics to remote regions, Nat. Commun., 11, 1-11, https://doi.org/10.1038/s41467-020-172019, 2020

Fei, Y., Huang, S., Zhang, H., Tong, Y., Wen, D., Xia, X., Wang, H., Luo, Y. and Barceló, D.: Response of soil enzyme activities and bacterial communities to the accumulation of microplastics in an acid cropped soil, Sci. Total Environ., 707, 135634, https://doi.org/10.1016/j.scitotenv.2019.135634, 2020.

Fuller, S. and Gautam, A.: A procedure for measuring microplastics using pressurized fluid extraction, Environ. Sci. Technol., 50, 5774-5780, https://doi.org/10.1021/acs.est.6b00816, 2016.

Geyer R., Jambeck J. R., and Law K. L.: Production, use, and fate of all plastics ever made, Sci. Adv., 3, e1700782, https://doi.org/10.1126/sciadv.1700782, 2017.

Gregory, M. R.: Accumulation and distribution of virgin plastic granules on New Zealand beaches, New Zealand J. Mar. Freshw. Res., 12, 399-414, https://doi.org/10.1080/00288330.1978.9515768, 1978.

Han, X., Lu, X., and Vogt, R. D.: An optimized densitybased approach for extracting microplastics from soil and sediment samples, Environ. Pollut., 254, 113009, https://doi.org/10.1016/j.envpol.2019.113009, 2019.

He, P., Chen, L., Shao, L., Zhang, H., and Lü, F.: Municipal solid waste (MSW) landfill: A source of microplastics? - Evidence of microplastics in landfill leachate, Water Res., 159, 38-45, https://doi.org/10.1016/j.watres.2019.04.060, 2019.

Huang, Y., Liu, Q., Jia, W., Yan, C., and Wang, J.: Agricultural plastic mulching as a source of microplastics in the terrestrial environment, Environ. Pollut., 260, 114096, https://doi.org/10.1016/j.envpol.2020.114096, 2020.

Huerta Lwanga, E., Vega, J. M., Quej, V. K., de los Angeles Chi, J., del Cid, L. S., Chi, C., Escalona Segura, G., Gertsen, H., Salánki, T., van der Ploeg, M., Koelmans, A. A., and Geissen, V. A.: Field evidence for transfer of plastic debris along a terrestrial food chain, Sci. Rep, 7, 1-7, https://doi.org/10.1038/s41598-01714588-2, 2017.

Kaiser, M. and Berhe, A. A.: How does sonication affect the mineral and organic constituents of soil aggregates? - A review, J. Plant Nutr. Soil Sci., 177, 479-495, https://doi.org/10.1002/jpln.201300339, 2014.

Karthik, R., Robin, R. S., Purvaja, R., Ganguly, D., Anandavelu, I., Raghuraman, R., Hariharan, G., Ramakrishna, A., and Ramesh, R.: Microplastics along the beaches of southeast coast of India, Sci. Total Environ., 645, 1388-1399, https://doi.org/10.1016/j.scitotenv.2018.07.242, 2018.

Lambert, S., Sinclair, C., and Boxall, A.: Occurrence, degradation, and effect of polymer-based materials in the environment, in: Reviews of Environmental Contamination and Toxicology,
227, 1-53, Springer, Cham, https://doi.org/10.1007/978-3-31901327-5_1, 2014.

Lehmann, A., Fitschen, K., and Rillig, M. C.: Abiotic and biotic factors influencing the effect of microplastic on soil aggregation, Soil Syst., 3, 21, https://doi.org/10.3390/soilsystems3010021, 2019.

Liu, M., Lu, S., Song, Y., Lei, L., Hu, J., Lv, W., Zhou, W, Cao, C., Shi, H., Yang, X., and He, D.: Microplastic and mesoplastic pollution in farmland soils in suburbs of Shanghai, China, Environ. Pollut., 242, 855-862, https://doi.org/10.1016/j.envpol.2018.07.051, 2018.

Ljung, E., Olesen, K. B., Andersson, P. G., Fältström, E., Vollertsen, J., Wittgren, H. B., and Hagman, M.: Mikroplaster i kretsloppet, Svenskt Vatten Utveckling Rapport, 13, 2018.

Lots, F. A., Behrens, P., Vijver, M. G., Horton, A. A., and Bosker, T.: A large-scale investigation of microplastic contamination: abundance and characteristics of microplastics in European beach sediment, Marine Pollut. Bull., 123, 219-226, https://doi.org/10.1016/j.marpolbul.2017.08.057, 2017.

Lv, W., Zhou, W., Lu, S., Huang, W., Yuan, Q., Tian, M., Lv, W., and He, D.: Microplastic pollution in ricefish co-culture system: A report of three farmland stations in Shanghai, China, Sci. Total Environ., 652, 1209-1218, https://doi.org/10.1016/j.scitotenv.2018.10.321, 2019.

Meixner, K., Kubiczek, M., and Fritz, I.: Microplastic in soilcurrent status in Europe with special focus on method tests with Austrian samples, AIMS Environ. Sci., 7, 174, https://doi.org/10.3934/environsci.2020011, 2020.

$\mathrm{Ng}$, E. L., Lwanga, E. H., Eldridge, S. M., Johnston, P., Hu, H. W., Geissen, V., and Chen, D.: An overview of microplastic and nanoplastic pollution in agroecosystems, Sci. Total Environ., 627, 1377-1388, https://doi.org/10.1016/j.scitotenv.2018.01.341, 2018.

Nizzetto L., Futter M., and Langaas S.: Are agricultural soils dumps for microplastics of urban origin?, Environ. Sci. Technol., 50, 10777-10779, https://doi.org/10.1021/acs.est.6b04140, 2016.

Piehl, S., Leibner, A., Löder, M. G., Dris, R., Bogner, C., and Laforsch, C.: Identification and quantification of macro-and microplastics on an agricultural farmland, Sci. Rep., 8, 1-9, https://doi.org/10.1038/s41598-018-36172-y, 2018.

Praagh, M. V., Hartman, C., and Brandmyr, E.: Microplastics in Landfill Leachates in the Nordic Countries, https://doi.org/10.6027/TN2018-557, 2018.

Ramos, L., Berenstein, G., Hughes, E. A., Zalts, A., and Montserrat, J. M.: Polyethylene film incorporation into the horticultural soil of small periurban production units in Argentina, Sci. Total Environ., 523, 74-81, https://doi.org/10.1016/j.scitotenv.2015.03.142, 2015.

Rezaei M., Riksen M. J., Sirjani E., Sameni A., and Geissen V.: Wind erosion as a driver for transport of light density microplastics, Sci. Total Environ., 669, 273-281, https://doi.org/10.1016/j.scitotenv.2019.02.382, 2019.

Rillig, M. C., Lehmann, A., de Souza Machado, A. A., and Yang, G.: Microplastic effects on plants, New Phytol., 223, 1066-1070, https://doi.org/10.1111/nph.15794, 2019.

Schell, T., Rico, A., and Vighi, M.: Occurrence, fate and fluxes of plastics and microplastics in terrestrial and freshwater ecosystems, in: Reviews of Environmental Contamination and Toxicology (Continuation of Residue Reviews), 
https://doi.org/10.1007/398_2019_40, Springer, New York, NY, 2020.

Scheurer, M. and Bigalke, M.: Microplastics in Swiss floodplain soils, Environ. Sci. Technol., 52, 3591-3598, https://doi.org/10.1021/acs.est.7b06003, 2018.

Simon, M., van Alst, N., and Vollertsen, J.: Quantification of microplastic mass and removal rates at wastewater treatment plants applying Focal Plane Array (FPA)-based Fourier Transform Infrared (FT-IR) imaging, Water Res., 142, 1-9, https://doi.org/10.1016/j.watres.2018.05.019, 2018.

Six, J., Schultz, P. A., Jastrow, J. D., and Merckx, R.: Recycling of sodium polytungstate used in soil organic matter studies, Soil Biol. Biochem., 31, 1193-1196, 1999.

Steinmetz, Z., Wollmann, C., Schaefer, M., Buchmann, C., David, J., Tröger, J., Muñoz, K., Frör, O., and Schaumann, G. E.: Plastic mulching in agriculture. Trading short-term agronomic benefits for long-term soil degradation?, Sci. Total Environ., 550, 690705, https://doi.org/10.1016/j.scitotenv.2016.01.153, 2016.

Thompson R. C., Swan S. H., Moore C. J., and vom Saal F. S.: Our plastic age, Phil. Trans. R. Soc. B., 364, 1973-1976, https://doi.org/10.1098/rstb.2009.0054, 2009.

van den Berg, P., Huerta-Lwanga, E., Corradini, F., and Geissen, V., 2020: Sewage sludge application as a vehicle for microplastics in eastern Spanish agricultural soils, Environ. Pollut., 261, 114198, https://doi.org/10.1016/j.envpol.2020.114198, 2020.

Vollertsen, J. and Hansen, A. A.: Microplastic in Danish wastewater: Sources, occurrences and fate, The Danish Environmental Protection Agency, Environmental Project 1906, Copenhagen, Denmark, 2017.

Weithmann N., Möller J. N., Löder M. G., Piehl S., Laforsch C., and Freitag R.: Organic fertilizer as a vehicle for the entry of microplastic into the environment, Sci. Adv., 4, eaap8060, https://doi.org/10.1126/sciadv.aap8060, 2018.
Yu, X., Ladewig, S., Bao, S., Toline, C. A., Whitmire, S., and Chow, A. T.: Occurrence and distribution of microplastics at selected coastal sites along the southeastern United States, Sci. Total Environ., 613, 298-305, https://doi.org/10.1016/j.scitotenv.2017.09.100, 2018.

Zhang, G. S. and Liu, Y. F.: The distribution of microplastics in soil aggregate fractions in southwestern China, Sci. Total Environ., 642, 12-20, https://doi.org/10.1016/j.scitotenv.2018.06.004, 2018.

Zhang, S., Yang, X., Gertsen, H., Peters, P., Salánki, T., and Geissen, V.: A simple method for the extraction and identification of light density microplastics from soil, Sci. Total Environ., 616, 10561065, https://doi.org/10.1016/j.scitotenv.2017.10.213, 2018.

Zhang, S., Liu, X., Hao, X., Wang, J., and Zhang, Y.: Distribution of low-density microplastics in the mollisol farmlands of northeast China, Sci. Total Environ., 708, 135091, https://doi.org/10.1016/j.scitotenv.2019.135091, 2020.

Zhou, B., Wang, J., Zhang, H., Shi, H., Fei, Y., Huang, S., Tong, Y., Wen, D., Luo, Y., and Barceló, D.: Microplastics in agricultural soils on the coastal plain of Hangzhou Bay, east China: Multiple sources other than plastic mulching film, J. Hazard. Mater., 388, 121814, https://doi.org/10.1016/j.jhazmat.2019.121814, 2020.

Zhou, Y., Liu, X., and Wang, J.: Characterization of microplastics and the association of heavy metals with microplastics in suburban soil of central China, Sci. Total Environ., 694, 133798, https://doi.org/10.1016/j.scitotenv.2019.133798, 2019.

Zubris, K. A. V. and Richards, B. K.: Synthetic fibers as an indicator of land application of sludge, Environ. Pollut., 138, 201-211, https://doi.org/10.1016/j.envpol.2005.04.013, 2005. 